\title{
PENEGAKAN HUKUM \\ PENANGKAPAN IKAN SECARA ILEGAL
}

\author{
Ashar Sinilele \\ Fakultas Syariah dan Hukum UIN Alauddin Makassar
}

\begin{abstract}
The various forms of fishing carried out by fishermen in the waters of the Gulf of Bone, the most prominent is the use of fish bombs, namely with explosives. Fishing using explosives is illegal so that law enforcement officers, especially the police, must act decisively by hunting down and arresting fish bombers. To reduce illegal fishing in the waters of the Gulf of Bone, the police carry out continuous patrols. However, efforts to eradicate fish bombardment behaviors are constrained by the limited police personnel, as well as police facilities and infrastructure.
\end{abstract}

\section{Keywords:}

Fish Bombs, Police, Facilities and Infrastructure, Law Enforcement

\begin{abstract}
Abstrak
Dari berbagai bentuk penangkapan ikan yang dilakukan oleh para nelayan di perairan Teluk Bone, yang paling menonjol adalah penggunaan bom ikan, yaitu dengan bahan peledak. Penangkapan ikan dengan menggunakan bahan peledak merupakan tindakan ilegal sehingga membuat aparat penegak hukum, utamanya pihak kepolisian, harus bertindak tegas dengan memburu dan menangkap pelaku pemboman ikan. Untuk mengurangi penangkapan ikan secara ilegal di perairan Teluk Bone, pihak kepolisian melaksanakan patroli secara terus menerus. Namun, upaya memberantas perilaku pemboman ikan terkendala pada terbatasnya personil kepolisian, serta sarana dan prasarana kepolisian.
\end{abstract}

Kata Kunci:

Bom Ikan, Kepolisian, Sarana dan Prasarana, Penegakan Hukum

\section{A. PENDAHULUAN}

1. Latar Belakang

$\mathrm{P}$ erkembangan dunia secara global akan memberikan dampak bagi kehidupan masyarakat. Sehingga dengan majunya perekonomian disertai perkembangan teknologi yang semakin pesat dan sarana yang semakin memadai juga menimbulkan banyak masalah yang muncul di tengah-tengah masyarakat. Salah satu yang nampak yang menjadi sorotan terutama perkembangan aktivitas 
masyarakat termasuk di perairan serta di laut pada umumnya, maka untuk menciptakan kesehjahteraan diperlukan aktivitas pendukung yang memadai sesuai yang telah ditetapkan dalam peraturan perundang-undangan yang berlaku di Republik Indonesia.

Berkaitan dengan hal tersebut, seiring dengan kemajuan teknologi dewasa ini, maka tentu berdampak juga terhadap berbagai hal termasuk kepentingan pribadi selalu diutamakan dari pada kepentingan umum. Untuk menjaga ketertiban di laut agar senantiasa tidak menjadi incaran para nelayan yang ingin menangkap ikan secara illegal, maka dibuatkan aturan hukum yang dijadikan pedoman dalam menangkap ikan, hal tersebut dilakukan oleh Pemerintah agar ikan yang ada dilaut menjadi sumber pendapatan bangsa Indonesia dengan demikian maka fungsi hukum sangat diharapkan dalam mengurangi terjadinya berbagai bentuk penangkapan ikan yang dilakukan oleh para nelayan di laut untuk mendapatkan ikan secara illegal. Hal ini perlu peningkatan dan memberdayakan bagaimana fungsi hukum terhadap ketertiban dari berbagai macam bentuk adanya ancaman yang dapat membahayakan kelangsungan habitat kekayaan yang ada di laut.

Dengan banyaknya bentuk dan cara yang dilakukan masyarakat dalam menangkap ikan utamanya terhadap penggunaan bahan peledak seperti Bom, bius serta pukat harimau yang dilakukan oleh masyarakat untuk memperoleh ikan sehingga banyak nelayan tindak mengindahkan aturan demi kepentingan yang saat ini, maka hukum sangat berperan terhadap sanksi yang melakukan penangkapan ikan yang tidak sesuai dengan aturan sebagai mana yang telah ditetapkan dalam Undang-undang No.31 Tahun 2004 tentang perikanan. Sehubungan dengan semakin meningkatnya berbagai bentuk atau cara yang dilakukan oleh masyarakat dalam menangkap ikan sehingga perlu adanya sanksi yang tegas terhadap yang melakukan pelanggaran dalam menangkap ikan menggunakan alat Bom yang mana sangat bertentangan dalam undang-undang N0 31 Tahun 2004 tentang perikanan banyak mengalami kendala dalam pelaksanaan di laut.

Berbagai upaya yang dilakukan oleh aparat Kepolisian utamanya Polisi Laut saat ini telah banyak membuahkan hasil dalam memberantas berbagai bentuk pelanggaran utamanya terhadap bom ikan, tetapi juga masih mempunyai kendala yang dihadapi sekarang ini, upaya yang maksimal juga sudah memperlihatkan hasil yang memadai namun masih banyak masalah yang belum bisa teratasi secepat mungkin karena memerlukan waktu yang lama dan harus dilaksanaan secara terus menerus dalam melakukan upaya tersebut.

\section{Rumusan Masalah}

Berdasarkan latar belakang tersebut di atas, maka dirumuskan masalah sebagai berikut :

1. Bagaimana bentuk penangkapan ikan yang dilakukan secara ilegal?

2. Bagaimana penegakan hukum pelaku penangkapan ikan secara ilegal? 


\section{Tujuan}

Adapun tujuan yang ingin dicapai sebagai berikut:

1. Untuk mengetahui bagaimana bentuk penangkapan ikan yang dilakukan oleh masyarakat.

2. Untuk mengetahui penegakan hukum bagi penangkap ikan secara illegal.

\section{Kegunaan}

Adapun kegunaan ini adalah :

1. Memberikan masukan bagi penegak hukum tentang pelanggaran yang dilakukan masyarakat dalam menangkap ikan.

2. Berguna bagi masyarakat terhadap perkembangan serta usaha dalam menemukan ilmu pengetahuan yang baru.

\section{B. TINJAUAN PUSTAKA}

\section{Peledakan.}

Banyak bahan peledak yang di gunakan oleh masyarakat terutama dalam melakukan penangkapan ikan, disini juga merupakan bagian dari kriminalitas yang berasal dari kata Crime yang artinya kejahatan karena menunjukkan suatu perbuatan atau tingkah laku kejahatan. Kriminologi menggariskan bahwa kejahatan antara lain dilakukan oleh manusia yang pembawaan atau wataknya cenderung untuk melakukan kejahatan atau kriminal.( Ahmad Ali 2003:186).

Demikian pula J.E Sahetapy dan B, Marjono Reksodipuro yang mengatakan bahwa:

"Kejahatan adalah setiap perbuatan, termasuk kelalaian yang dilarang oleh hukum publik untuk melindungi masyarakat dan diberi sanksi berupa pidana oleh negara. Perbuatan tersebut diberi hukum karena melanggar norma-norma yang berlaku di masyarakat, harapan yang mengenai tingkah laku yang patut dari seseorang warga negaranya" (Abdulsyani, 1987 : 13).

\section{Penangkapan ikan secara ilegal}

Dalam sejarah, laut terbukti telah mempunyai berbagai fungsi antara lain, sebagai sumber makanan bagi umat manusia, sebagai jalan raya perdagangan, sebagai sarana untuk penaklukkan, sebagai tempat pertempuran, sebagai tempat bersenang-senang dan rekreasi dan sebagai alat pemisah atau pemersatu bangsa.

Bila diperhatikan dengan saksama bahwa masalah perlindungan perikanan dilihat adanya dua macam kegiatan yang perlu mendapat perhatian selanjutnya :

1. Perlindungan perikanan dan kekayaan hayati laut di laut lepas yang berjauhan dari pantai negara di mana para nelayan menangkap ikan di tempat itu. Bila daerah penangkapan ikan itu terdapat nelayan dari suatu negara tertentu saja maka negara yang bersangkutan wajib mengambil tindakan perlindungan yang perlu. Hal yang menarik dari ketentuan tentang masalah ini ialah diakui 
adanya suatu kepentingan istimewa dari negara pantai dalam mempertahankan produktivitas kekayaan hayati laut.

2. Kepentingan istimewa suatu negara pantai dalam perlindungan perikanan di laut lepas yang tak berbatasan dengan pantainya sedangkan nelayan - nelayan tidak menangkap ikan di daerah tersebut. Nampaknya suatu jaminan yang cukup banyak terhadap negara pantai dalam hal perlindungan perikanan di laut lepas. Di sinilah nampak jaminan kepentingan istimewa negara tersebut.

\section{Kekayaan dan Fungsi Pengelolaan}

Semakin disadari bahwa laut selain berfungsi sebagai penghubung wilayah satu dan lainnya dalam memperlancar hubungan transportasi, juga kekayaan yang terkandung didalamnya sangat menopang hidup dan kehidupan rakyat banyak. Namun dengan potensi kekayaan yang ada dapat menimbulkan bencana apabila dalam pengelolaannya tanpa memperhatikan batas kemampuan alam. kebebasan tentang perikanan dalam pasal ini namun ada pula pembatasan-pembatasan tertentu, baik yang ditetapkan dalam perjanjian yang diadakan oleh negara-negara maupun pembatasan-pembatasan oleh kepentingan-kepentingan dan hak-hak negara pantai, serta ketentuan-ketentuan perlindungan perikanan sebagaimana ditetapkan dalam undang - undang. Bila diperhatikan dengan saksama bahwa masalah perlindungan perikanan perlu diperhatikan dengan penerapan undangundang.

Secara prefentif untuk mencegah terjadinya kerusakan lingkungan laut sebagai akibat dari penangkapan ikan dengan dasar Undang-undang dan peraturan pelaksanaannya telah diatur mengenai masalah pengelolaan sumber daya ikan dengan prinsip pemenfaatannya ditujukan untuk sebesar-besar kemakmuran rakyat, dengan tidak meninggalkan ketentuan yang ditetapkan oleh Menteri yang berwenang, yaitu mengenai :

1. Alat penangkapan ikan yang diizinkan

2. Syarat-syarat teknis perikanan yang harus dipenuhi oleh kapal perikanan

3. Jumlah yang boleh ditangkap dan jenis serta ukuran ikan yang tidak boleh ditangkap

4. Memperhatikan daerah, jalur dan waktu atau musim penangkapan

5. Pencegahan pencemaran dan kerusakan, rehabilitasi dan peningkatan sumber daya ikan serta lingkungannya.

6. Penebaran ikan jenis baru

7. Pembudidayaan ikan dan perlindungannya

Bentuk ketentuan demikian dikeluarkan selain untuk pencegahan seperti dimaksud di atas, juga menunjukkan kerawanan laut sehingga perlu penanganan yang seksama dan tidak hanya memperhatikan kepentingan sesaat saja.

Undang-undang Nomor 9 tahun 1988 tentang perikanan sudah tidak dapat mengantisipasi perkembangan pembangunan perikanan saat ini dan masa yang 
akan datang, karena di bidang perikanan telah terjadi perubahan yang sangat besar, baik yang berkaitan ketersediaan sumber daya ikan maupun perkembangan metode pengelolaan perikanan yang semakin efektif, efisien, dan modern, sehingga pengelolaan perikanan perlu dilakukan secara berhati-hati dengan berdasarkan asas manfaat, keterbukaan, efesiensi dan kelestarian yang berkelanjutan.

Pelaksanaan penegakan hukum di bidang perikanan menjadi sangat penting dan strategis dalam rangka menunjang pembangunan perikanan secara terkendali dan sesuai dengan asas pengelolaan perikanan, sehingga pembangunan perikanan dapat berjalan secara berkelanjutan. Oleh karena itu adanya kepastian hukum merupakan suatu kondisi yang mutlak diperliukan. Dalam undang-undang ini lebih memberikan kejelasan dan kepastian hukum terhadap penegakan hukum atas tindak pidana di bidang perikanan, yang mencakup penyidikan, penuntutan, dan pemeriksaan di sidang pengadilan dengan demikian perlu diatur secara khusus mengenai kewenangan penyidik, penuntut umum dan hakim dalam menangani tindak pidana di bidang perikanan.

Dalam menjalankan tugas dan wewenang penyidikan penuntut umum serta pemeriksaan di sidang pengadilan di samping mengikuti hukum acara yang diatur dalam Undang-Undang Nomor 8 Tahun 1981 tentang kitab Undang-Undang ini diatur mengenai pembentukan pengadilan perikanan di lingkungan peradilan umum yang untuk pertama kali di bentuk di lingkungan Pengadilan Negeri Jakarta Utara, Medan, Pontianak, Blitung dan Tual. Namun demikian mengingat masih diperlukan persiapan maka pengadilan perikanan yang telah dibentuk tersebut, baru melaksanakan tugasnya dan fungsinya paling lambat 2 tahun terhitung sejak tanggal undang-undang ini berlaku. Pengadilan perikanan tersebut bertugas dan berwenang memeriksa, mengadili dan memutus tindak pidana di bidang perikanan yang dilakukan oleh majelis hakim yang terdiri atas satu orang hakim karir pengadilan Negeri dan dua orang hakim ad hoc.

\section{Pelanggaran Penangkapan Ikan secara ilegal}

Secara garis besar sebab-sebab yang dapat menimbulkan terjadinya pelanggaran terdiri dari dua faktor yaitu faktor-faktor yang bersumber dari dalam individu sendiri atau faktor internal dan faktor-faktor yang bersumber dari luar individu atau faktor eksternal.

Dalam buku Achmad Ali ( 1996 : 89 ) menyatakan bahwa sebab-sebab terjadinya kejahatan atau kriminalitas pada umumnya adalah :

1. faktor intern, yakni faktor-faktor yang bersumber dari dalam diri pelaku, seperti perilaku yang menderita kelainan jiwa atau sifat khas tertentu dalam diri pribadinya, misalnya emosional dan mudah tersinggung akibat rasa rendah diri.

2. faktor ekstern, yakni faktor-faktor yang bersumber dari luar diri perilakunya, seperti faktor keluarga, faktor lingkungan kumuh dan kebijaksanna perkotaan, penyalahgunaan obat-obatan terlarang dan minuman keras dan kebutuhan ekonomi yang mendesak, dan lain-lain. 
Kebanyakan pelaku pencurian disebabkan karena pengaruh lingkungan sosial, baik karena adanya kesempatan maupun karena adanya pengaruh orang lain yang mendorong munculnya keinginan untuk melakukan perbuatan menyimpang itu.

\section{Penegakan Hukum Penangkap Ikan secara ilegal}

Suatu prihal gejala sosial dalam bentuk tindakan tindakan yang menyimpang dari apa yang ditentukan dalam perundang-undangan, sepanjang menyangkut presedur akan sangat menarik. Untuk kepentingan itu perlu diungkapkan kondisikondisi sosial yang membawa pengaruh sehingga mengakibatkan terjadinya tindakan-tindakan yang menyimpang itu yang banyak melakukan penangkapan ikan secara ilegal.

\section{Penangkapan ikan dalam Perspektif Dalam Hukum}

Paling tidak terdapat tiga perspektif terhadap objek studi yang penting dalam perkembangan bidang pengetahuan ilmiah kriminologi yang pertumbuhannya dipengaruhi baik oleh perubahan-perubahan politik, ekonomi, sosial maupun pengaruh ideologi.

1. Perspektif yang menekankan pada sebab kejahatan dalam diri individu. Diasumsikan terdapatnya perbedaan-perbedaan antara penjahat dengan bukan penjahat, dan penelitian-penelitian kriminologis ditujukan pada penemuan dasar dari perbedaan-perbedaan tersebut. Pencarian sebab-sebab kriminalitas dalam keunikan ciri-ciri penjahat didasarkan pada perspektif koreksional tentang kejahatan. Perspektif ini terutama memperhatikan pertanyaan-pertanyaan mengenai penyebab atau etiologi. Tugas utama adalah menemukan akar sebabsebabnya prilaku jahat dalam rangka menghapuskannya dari lingkungan masyarakat. Dari analisa biologis, psikologis sampai psikologis sosial penjahat tekanannya adalah pada diagnosa pragnosa dan perbaikan.

2. Lingkaran penyebab diperluas dengan suatu pergeseran fokus dari individu pada kondisi-kondisi yang menghasilkan penjahat. Konsepsi kejahatan sebagai hasil sistem sosial adalah perspektif yang kian banyak dianut dalam kriminologi. Nampak bahwa teori-teori mengenai macam-macam lingkungan menekankan pada struktur kesempatan yang berbeda, kemiskinan, rasisme dan lain-lain sebagai faktor - faktor penyebab yang penting. Sebab-sebab kriminalitas menjangkau pula keluarga, kelompok sepermainan dan komuniti. Penjahat dipandang sebagai suatu hasil normal dari kondisi - kondisi yang buruk dan patologis. Di sini, perbaikan dari kondisi penyebab disarankan melalui proyekproyek rehabilitasi lingkungan setempat. Ditingkatkannya latihan-latihan kerja, program-program aksi sosial dan perbaikan sosial secara umum.

\section{Perlindungan Zona Ekonomi Laut}

Lahirnya Undang-undang No 5 tahun 1983 tentang zona ekonomi ini merupakan ralisasi juridis perluasan wilayah laut utamanya yang menyangkut keadaan ekonomi dalam pengelolaan, pengawasan dan pelestariannya, sehingga 
upaya untuk meningkatkan kesejahteraan bangsa dengan cara memanfaatkan sumber daya alam laut dapat dilaksanakan dengan sebaik-baiknya.

Rejim hukum internasional tentang ZEEI yang telah dikembangkan oleh masyarakat internasional dimaksudkan untuk :

1. Melindungi negara dari bahaya kemungkinan dihabiskannya sumber daya alam hayati di dekat pantainya oleh kegiatan negara-negara lain dalam mengelola perikanan berdasarkan rejim laut bebas. Dengan bantuan bahwa sumber daya alam hayati selain tidak mengenal batas wilayah juga akan dapat pulih kembali, namun tidak menutup kemungkinan habisnya sumber tersebut apabila tidak memperhatikan jumlah tangkapan dan frekwensi penangkapan

2. Melindungi kepentingan-kepentingan negara pantai di bidang pelestarian lingkungan laut serta penelitian ilmiah kelautan dengan upaya memanfaatkan sumber daya alam di zona tersebut.

Pengaruh zona tersebut sampai jarak maksimum yang ditetapkan dalam konvensi hukum laut, bukan meninggalkan kepentingan negara-negara lain untuk memakai fasilitas lautan, namun tetap memberikan hak-hak yang sama dalam pembudidayaan laut, sehingga baik negara berpantai maupun negara tidak berpantai dapat menikmati kekayaan laut dan tidak saling dirugikan.

\section{METODE PENELITIAN}

\section{Lokasi Penelitian}

Adapun tempat penelitian yaitu di wilayah peraiaran Teluk Bone Luwu dengan alasan bahwa di perairan tersebut banyak dijumpai terjadinya penangkapan ikan dengan menggunakan bahan peledak seperti bom, bius dan alat sejenisnya yang tentunya merugikan negara termasuk merusak ekosistem di laut yang merupakan pelanggaran yang betentangan dengan Undang-Undang Nomor 31 Tahun 2004 Tentang Perikanan.

\section{Populasi}

Populasi dalam penelitian ini adalah seluruh pelaku atau orang yang melakukan pelanggaran yang secara langsung tertangkap dan telah mempunyai kekuatan hukum tetap yang jumlahnya 20 orang

\section{Jenis dan Sumber Data}

Jenis data yang diharapkan untuk diperoleh dalam penelitian ini adalah sebagai berikut:

1. Data primer, yaitu data yang diperoleh secara langsung dari pihak kepolisian setempat dan utamanya bagi responden yang tertangkap dalam melakukan penangkapan ikan dengan bahan peledak.

2. Data Sekunder, yaitu data yang diperoleh dari dokumen atau dari buku literatur yang menyangkut tentang kejahatan dan lain sebagainya, lebih khusus kejahatan 
di laut berkaitan dengan penggunaan bahan peledak untuk mendapatkan ikan secara illegal.

\section{Teknik Pengumpulan Data}

Teknik pengumpulan data yang digunakan adalah :

1. Studi Pustaka

Penelitian ini dilakukan untuk mengumpulkan data melalui dokumen, catatancatatan penting, laporan maupun berbagai literatur atau karya ilmiah yang berkaitan dan mendukung penelitian ini.

2. Studi Lapang

Untuk mengetahui data yang akurat dan objektif melalui penelitian dilapangan digunakan teknik

(a) Observasi, yaitu mengamati secara langsung objek penelitian atau keadaan yang berkaitan dengan masalah penelitian. Teknik ini dilakukan dengan terjung langsung dilaut melihat berbagai bentuk kejahatan penggunaan bahan peledak oleh nelayan untuk memperoleh ikan lebih banyak secara ilegal.

(b) Wawancara

Wawancara adalah tanya jawab secara lisan antara dua orang atau lebih yang dilakukan secara langsung. Wawancara berguna untuk mendapatkan data secara langsung. Wawancara dilakukan terhadap responden yang telah di tetapkan, demikian pula dengan beberapa informan lainnya yang dianggap mengetahui hal-hal yang dikaji.

\section{PEMBAHASAN}

\section{Penangkapan ikan yang dilakukan secara illegal.}

Berbagai usaha dan bentuk sebagai usaha dalam mencermati situasi sekarang ini dimana banyak orang menangkap ikan secara tidak wajar atau menggunakan bahan peledak, maka dengan itu sangat bertentangan dengan hukum atau perundang-undangan yang berlaku. Sebagaimana diatur dalam undang-undang Nomor 31 tahun 2004 tentang perikanan, dimana sudah diatur bahwa seseorang menangkap ikan harus memakai alat yang standar dan tidak diperbolehkan memakai bom, dan bius ikan. Dengan mencermati berbagai macam dan bentuk dalam melakukan penangkapan ikan di wilayah perairan teluk Bone selama ini sebagian dari masyarakat menangkap ikan itu sebagai wadah dalam memperoleh rejeki, namun di balik itu sebagian dari masyarakat nelayan juga melakukan penangkapan ikan secara illegal, yaitu dengan menggunakan bahan-bahan terlarang yang berarti pelanggaran terhadap peraturan hukum yang berlaku, seperti Undangundang Nomor 31 tahun 2004 tentang perikanan.

Dari berbagai bentuk penangkapan ikan yang dilakukan oleh para nelayan di perairan Teluk Bone seperti yang disebutkan di atas, yang paling menonjol adalah pemboman ikan dengan bahan peledak. Frekwensi terjadinya penangkapan ikan 
dengan menggunakan bahan peledak ikan secara illegal oleh para nelayan yang terjadi di perairan Teluk Bone dapat dilihat pada tabel berikut ini :

Tabel 1

Bentuk penangkapan ikan yang dilakukan diTeluk Bone

\begin{tabular}{|c|c|c|c|}
\hline No & Jenis Penangkapan & Jumlah & Persentase \\
\hline 1 & Pemboman & 35 & 52 \\
2 & Pembiusan & 13 & 19 \\
3 & Peracunan & 12 & 17 \\
4 & Potasium & 8 & 12 \\
\hline & Jumlah & 68 & 100 \\
\hline
\end{tabular}

Sumber data : Data Primer diolah 2018

Dengan melihat keadaan tersebut, maka dapat dikatakan bahwa sebenarnya pelaku peledakan di laut tidak sembarang orang karena pelaku pemboman ikan yang diharapkan adalah nilai yang besar atau ikan yang ingin didapatkan adalah ikan yang bernilai ekspor yang bernilai harganya mahal dan cepat laku, dibandingkan dengan menggunakan alat yang standar yang hanya mendapatkan ikan biasa dan berpariasi pula. Pelaku peledakan dengan menggunakan bom ikan serta alat yang membahayakan lainnya, kurang memiliki kepekaan terhadap kelestarian lingkungan hidup karena dengan menggunakan bahan peledak di laut semua ikan termasuk karang-karang akan hancur dan akan punah yang habitatnya bisa punah dan tidak akan tumbuh lagi.

Banyaknya bentuk peledakan yang terjadi di perairan Teluk Bone selama ini, membuat aparat pemerintah maupun pihak kepolisian dengan tanggap terhadap kejadian tersebut, dan jika kejahatan itu dibiarkan berlanjut sangat merugikan negara dan kelangsungan hidup dari berbagai ekosistem di laut

Oleh karena dampak yang dapat ditimbulkan dengan penggunaan potasium jauh lebih besar, makanya masyarakat nelayan lebih banyak memilih menggunakan pemboman ikan, karena resiko atau dampak yang ditimbulkan lebih kecil yaitu hanya sekitar dimana bom ikan itu diledakkan maka yang mengalami kerusakan hanyalah yang berada disekitar tempat itu saja.

Hal ini menunjukkan bahwa pelanggaran yang dilakukan nelayan di laut untuk memperoleh ikan dengan cara pemboman sangat besar jumlahnya di banding bentuk lainnya.

Namun dalam penelitian ini membuktikan salagum handak ini adalah suatu bentuk penangkapan ikan yang merajalela dilakukan sekelompok yang tidak mempunyai pekerjaan. Dan salah satu bentuk dari ketidak mampuan malakukan pekerjaan yang baik yang selama ini tidak dapat diatasi oleh pihak kepolisian karena susahnya melacak dan membuktikannya karena kapan dia mengetahui dan melihat petugas maka semua bahan-bahan yang terlarang itu akan dibuang dilaut, karena diketahui bahwa di perairan Teluk Bone adalah selat yang sangat luas, dimana jika petugas lewat mereka akan tidak melakukan aktivitas seperti biasanya. Keadaan ini 
masih juga diperaktekkan para orang-orang yang tidak bertanggung jawab terhadap keamanan lingkungan dan daerahnya.

Selain melakukan pemboman ikan, maka yang menempati urutan kedua dalam bentuk cara memperoleh ikan di laut yaitu dengan menggunakan pembiusan ikan, yang selama ini banyak pula di lakukan oleh sebagian masyarakat nelayan. Dengan pembiusan ikan di laut banyak menimbulkan kerugian, bukan hanya kerusakan habitat ikan dengan banyaknya ikan yang mati, kurang enak dimakan, lagipula kesehatan konsumen dapat terganggu karena pengaruh dari obat bius yang dipergunakan itu. Olehnya itu untuk memperoleh ikan di laut bentuk pembiusan sebaiknya dihindari.

Untuk mengetahui tingginya tingkat pembiusan ikan di laut dapat dilihat jawaban responden seperti dibawah ini sebagai berikut berikut :

Memperhatikan hasil responden nampak bahwa pembiusan ikan di perairan teluk Bone oleh masyarakatnya masih sangat tinggi penggunaannya yaitu sampai pada standar 12 kali pertahun.

Dengan demikian dalam Pasal 8 Undang-undang Nomor 31 tahun 2004 seharusnya menjadi pedoman bagi masyarakat khususnya pihak kepolisian dalam memberantas berbagai bentuk kejahatan penangkapan ikan yang dilakukan masyarakat di perairan Teluk Bone, yaitu di mana setiap orang dilarang melakukan penangkapan ikan dengan menggunakan bahan kimia, bahan biologis, bahan peledak, alat atau cara bangunan yang dapat merugikan negara dan atau membahayakan kelestarian hidup dan lingkungan perikanan republik Indonesia. Selama ini di wilayah perairan Teluk Bone para nelayan dalam melakukan penangkapan ikan masih banyak menggunakan bahan-bahan seperti disebutkan di atas. Sehingga dengan demikian praktek pemboman ikan yang dilakukan di Teluk Bone masih tergolong tinggi.

\section{Penegakan hukum pelaku penangkapan ikan secara ilegal.}

Penggunaan bahan peledak yang dengan populer adalah dengan Bom ikan yang selama ini marak dilakukan oleh masyarakat nelayan dalam menangkap ikan, membuat aparat penegak hukum utamanya pihak kepolisian harus bertindak tegas dalam melaksanakan tugasnya, dengan demikian aparat dengan tegas memburu dan menangkap pelaku pemboman ikan yang secara illegal menangkap ikan.

Dalam menangani kasus peledakan di perairan Teluk Bone, pihak kemanan atau kepolisian tak segan-segan mengeluarkan biaya yang besar dalam memberantas berbagai bentuk kejahatan atau yang menggunakan bahan yang terlarang atau Bom dalam penangkapan ikan. Dengan kesiagaan pihak kepolisian di laut dalam mengantisipasi terjadinya peledakan diperairan Teluk Bone, akhirnya petugas telah berhasil menangkap nelayan yang telah melakukan pemboman ikan di wilayah perairan Teluk Bone.

Di samping pemboman ikan dengan bahan peledak,pembiusan ikan di wilayah perairan Teluk Bone juga masih banyak dijumpai. Dengan demikian aparat pihak 
polisi laut siap siaga setiap saat dalam melakukan tugasnya meneggakkan hukum di laut, terbukti pihak kemanan atau pihak kepolisian mampu menangkap pelaku peledakan dengan berbagai bentuk dan jenis yang dilakukan oleh pengguna peledakan di wilayah perairan Teluk Bone.

Memperhatikan berbagai macam bentuk pelanggaran yang sering terjadi di perairan Teluk Bone saat ini, maka sangat terasa menjadi perhatian yang serius oleh aparat keamanan laut, sehingga masalah penangkapan ikan yang terjadi di laut saat ini sulit di atasi oleh pihak kepolisian, mengingat aparat yang sangat terbatas dan jauh dari tempat itu apalagi kita ketahui bahwa perairan Teluk Bone sangat luas sehingga aparat kepolisian tidak dapat mengatasi hal tersebut. Segala macam bentuk telah dilakukan oleh pihak kepolisian dalam menjaga ketertiban dan keamanan di perairan Teluk Bone. Adapun bentuk dan upaya yang dilakukan pihak kepolisian agar tidak terjadi penangkapan ikan secara illegal dengan menggunakan bahan peledak seperti Bom atau bahan-bahan lainnya yang banyak mengorbankan ekosistem di laut dan menimbulkan kerugian negara cukup besar dapat di lihat dalam uraian di bawah ini:

\section{Patroli Malam}

Patroli malam adalah suatu bentuk yang dilakukan dalam rangka menghindari meningkatnya penyalahgunaan penangkapan ikan dengan menggunakan alat peledak terutama dengan menggunakan Bom yang sering terjadi di perairan Teluk Bone. Terbukti bahwa dengan diadakannya patroli secara terus menerus yang dilakukan aparat kepolisian, maka terasa tingkat penggunaan bahan peledak yang terjadi di laut mengalami penurunan dibanding sebelumnya. Sebagaimana dituturkan oleh beberapa responden sebagai berikut :

a. Amir, 52 tahun mengatakan bahwa selama diadakannya patroli di setia malam oleh pihak kepolisian secara signifikan tingkat peledakan dengan menggunakan bom ikan sangat menurun. Perlu diketahui bahwa selain penangkapan ikan secara illegal penggunaan bahan peledak banyak pula kejahatan pada waktu malam yang dilakukan teruma dalam penangkap ikan dengan menggunakan bagang rambo yang berada di perairan Teluk Bone. Dengan adanya patroli malam tingkat kejahatan menurun karena dia mengetahui bahwa selalu ada pihak kepolisian yang siap siaga menjaga keamanan di perairan Teluk Bone. Jika dibandingkan sebelumnya. Sehingga apa yang diniatkan tidak dapat di nikmati. Olehnya itu sangat bermanfaat dilakukan patroli. Dengan demikian agar hal ini dapat terus menerus dilakukan oleh pihak kepolisian laut, semoga tidak semakin terjadi kejahatan dalam daerah perairan Teluk Bone.

b. Muhtadi, 55 Tahun, mengatakan sebenarnya para pembom ikan tidak akan berani datang ke laut membom ikan jika ada petugas di laut, dan bahkan para pembom ikan itu tidak segan-segan membuang alat yang digunakan membom ikan jika patroli polisi mendekat ke kapal yang di curigai membawa bahan peledak ikan 
c. Suyuti Hasan, 42 tahun mengatakan bahwa selama diadakannya patroli di setia malam oleh pihak kepolisian di perairan Teluk Bone secara signifikan tingkat kejahatan menurun, karena perlu diketahui bahwa banyaknya kejahatan pada waktu malam yang dilakukan teruma pihak pengguna bahan peledak yang berada di perairan Teluk Bone. Dengan adanya patroli malam tingkat penangkapan ikan dengan menggunakan bahan peledak mengalami penurunan, karena dia mengetahui bahwa selalu ada pihak kepolisian yang siap siaga menjaga keamanan di perairan Teluk Bone. Sehingga apa yang diniatkan tidak dapat di nikmati. Dengan demikian agar hal ini dapat terus menerus dilakukan, sehingga tidak semakin terjadi kejahatan dalam daerah perairan Teluk Bone.

Tentunya selama ini pihak keamanan atau kepolisian di laut sangat terbatas jumlahnya dan terbatas alat yang digunakan serta kapal yang digunakan ukurannya kecil sedangkan kondisi alam atau ombak yang besar sehingga akan terhalang dengan masalah tersebut, sehingga hal tersebut menjadi kendala utama dalam menangani berbagai bentuk penyalagunaan di laut.

Demikian pula terhadap biaya operasional yang terlalu tinggi dan sangat terbatas dalam menunjang keamanan di perairan Teluk Bone yang menjadi penyebab adanya berbagai jenis penggunaan bahan terlarang yang tidak dapat di atasi di laut.

Berbagai kendala yang di hadapi pihak kepolisian dalam memberantas berbagai bentuk pemboman ikan di perairan Teluk Bone antara lain:

1. Terbatasnya Personil Kepolisian

Salah satu faktor yang menyebabkan banyaknya permasalahan yang timbul di laut yang belum bisa teratasi secara baik karena selama ini masih terbatasnya jumlah personil kepolisian yang ada di laut yang melakukan patroli dibandingkan dengan banyaknya jumlah kasus nelayan yang melakukan penangkapanikan.

2. Terbatasnya Prasarana yang tersedia

Perlu diketahui bahwa sarana dan prasarana yang dimiliki oleh kepolisian di Teluk Bone juga terbatas, sehingga hal ini juga menjadi perhatian pihak polisi laut saat ini. Armada yang dimiliki masih sedikit dibanding luas wilayah dan jumlah nelayan yang harus di awasi. Dengan kemampuan yang dimiliki dalam menyiapkan armada kepolisian yang terbatas ini tentunya masih mempunyai celah tersendiri yang akan dimanfaatkan oleh nelayan yang memakai kapal yang besar yang tidak dapat dijangkau oleh pihak kepolisian.

3. Biaya Operasional yang Terbatas

Demikian juga selama ini sehingga masih dijumpai banyak pelaku terhadap penangkapan ikan secara illegal karena patroli kepolisian juga memperhatikan kendala ini dengan melakukan prioritas waktu tertentu dalam melakukan operasi di laut, karena jumlah biaya operasional yang masih terbatas. 
4. Faktor Alam

Faktor alam yang dimiliki perairan Teluk Bone merupakan salah satu faktor atau sebab sehingga selama ini masih banyak dijumpai penangkapan ikan secara illegal karena faktor alamnya. Dimana perlu diketahui bahwa Teluk Bone mempunyai banyak lempengan dan sangat panjang dan luas sehingga susah diintai oleh para polisi laut.

\section{E. KESIMPULAN DAN SARAN}

\section{Kesimpulan}

Berdasarkan apa yang telah dikemukakan di atas, maka dapat disimpulkan sebagai berikut:

1. Bahwa jenis-jenis kriminal yang banyak terjadi di perairan Teluk Bone adalah pemboman ikan, pembiusan ikan. Banyaknya orang melakukan pemboman ikan karena ingin cepat memperoleh ikan tanpa peduli kerugian yang ditimbulkan.

2. Untuk mengurangi penangkapan ikan secara illegal di perairan Teluk Bone, diharapkan dilakukan patroli secara terus menerus, namun dalam memberantas pemboman ikan di perairan Teluk Bone adalah terbatasnya personil kepolisian, serta sarana dan prasarana kepolisian yang ada.

\section{Saran - Saran}

Bahwa untuk menjaga keamanan adanya penangkapan ikan secara illegal di perairan Teluk Bone, maka disarankan sebagai berikut :

1. Pihak kepolisian khususnya kepolisian di laut agar menambah armada dan fasilitas dalam mendukung pengoperasian di laut.

2. Untuk menghindari dan mengurangi tindak kriminal maka seyokyanya perlu pembinaan dan tidak ada pengaturan untuk kepentingan pribadi. Dengan adanya tindakan serta sanksi yang berat maka para pelaku tidak akan mengulangi lagi kejahatan.

\section{Daftar Pustaka}

Abdulsyani, Sosiologi Kriminalitas, Remaja Karya Bandung, 1987.

Djarwanto, P.S, Pokok-pokok Metode Riset, Liberty Yokyakarta, 1990.

Eva Achjani, Kriminologi Rajawali pres, Jakarta, 2003.

Frans E. Likadja, Hukum Laut dan Undang-undang Perikanan, Ghalia Indonesia, Balai aksara, 1988.

Hadisuproto, P, Kenakalan remaja dan lingkungan Makalah seminar keluarga remaja perkotaan, jakarta 1989.

Joko Subagyo, Hukum Laut Indonesia, Rineka Cipta, Jakarta 2002. 
Kartono. K, Patologi Sosial, Rajawali pres, Jakarta 1983.

Radjab, M, Aspek-aspek sosiologis yang mempengaruhi masalah Kejahatan Pencurian di Kota madya Makassar, Skripsi S.1 Fisbud Unhas.

Saherodji, HH, Pokok-pokok Kriminologi, Aksara Baru, Jakarta, 1980.

Simanjuntak, B. Pengantar Kriminologi dan Patologi Sosial, Alumni, Bandung, 1977.

Soerdjono, R. Sukanto, Doktrin Kriminologi, Alumni Bandung, 1973.

Kriminologi Suatu pengantar, Ghalia Indonesia, 1981.

Soesilo, R Kriminologi ( Pengetahuan tentang sebab-sebab Kejahatan) Politea Bogor, 1976.

Undang-Undang Republik Indonesia Nomor 31 Tahun 2004. 